\title{
Health Dialogue Experiences of Students, Teachers and School Nurses in Swedish Health-promoting Schools
}

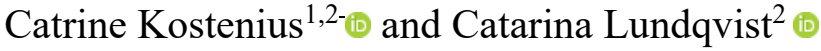 \\ ${ }^{1}$ Luleå University of Technology \\ ${ }^{2}$ Norrbotten Association of Local Municipalities, Luleå, Sweden
}

\begin{abstract}
Background and Purpose: According to Swedish law, all students are to be offered health dialogues with a school nurse, which helps to promote students' health literacy. However, research shows that the health dialogues are not being used to their fullest potential. This study explores how health dialogues are experienced by school actors - students, teachers and school nurses. Methods: The 93 participants from 14 municipalities in northern Sweden wrote open letters sharing their experiences with health dialogues. Phenomenological analyses were conducted on the letters to derive themes and subthemes. Results: Two themes with three sub-themes were identified, each that describe well-functioning health-promoting schools in which health promotion was seen as a shared practice among staff. In contrast, the participants expressed frustration or resignation with the challenges connected to health dialogues. Conclusion: When given a voice, school actors paint an informative collective picture of health dialogues. Based on our findings, we argue that health dialogues can promote students' health literacy and enable collaboration between different actors within educational systems. Furthermore, promoting health in school must be viewed as a common assignment for all school staff, and support from school leadership is needed to systematically use the results from health dialogues to inform effective health promotion practice.
\end{abstract}

(C) 2021 and CC-BY 4.0 licensed by the authors.

Keywords: education, health dialogues, health literacy, health promotion, phenomenological analysis

\section{Introduction}

Health is inextricably linked to education, as education is one of the most impactful determinants of public health (Gustafsson et al., 2010). Good health aids in the learning process, while a good in-school learning environment promotes good health among its students (Backman et al., 2012). Through national educational systems across Europe, health education is handled in varied ways. For example, in Finland, health education is a freestanding school subject that promotes and measures health literacy (Paakari et al., 2018). In Sweden, health promotion perspectives are integrated into daily pedagogical work in pre- and primary school, where teachers and school health staff share the responsibility of promoting health among their students (Swedish National Agency for Education, 2010). The Swedish national curriculum and government guidelines for school health services (SHS) articulate the need for collaborative efforts that transcend professional boundaries and include even pedagogical staff (Swedish National Agency for Education, 2010; National Board of Health and Welfare, 2016); however, this is not easily actualized (Rising-Holmström et al., 2015). According to the national curriculum and Swedish school law, the school should promote learning and harmonious development for all students while also paying attention to health and lifestyle issues (SFS, 2010:800). All students in preschool, grades 4 and 7, and the first year of high school are entitled to health dialogues with a 
school nurse. The health dialogues offer students an opportunity to reflect on their own conditions and choices to strengthen their ability to manage and live a healthy life and include information, counselling and learning based on the individual student's needs (Golsäter, 2012).

In connection with these health dialogues, students in the four northern regions of Sweden, fill out an on-line health questionnaire on their own or with the help of a guardian. These selfreported health questionnaires are ageappropriate and consists of 4 questions to preschool students and between 27-37 questions to the older students. The questions encompass their physical and mental health, dietary habits, physical activities, friends, school environment, home life, and leisure activities. According to Rising Holström et al. (2013), health questionnaires help schools understand students' subjective health and wellbeing; yet, in the regions, the results from these health questionnaires are not being used to their fullest potential. In Norrbotten, the most northern region of Sweden, the answers are collated into an anonymized database that has the potential to describe students' health on many levels (by each school, municipality, demographic features) from a longitudinal perspective (Region Norrbotten, 2019).

The Swedish National Board of Health and Welfare and the Swedish National Agency for Education (2016) clarify that "student health is part of the education and is intended to support students' development towards the educational goals" (p. 11). One way to ensure that student health is prioritized is by fulfilling the mandate that health dialogues be offered to all students that are entitled to this health service. However, the Swedish School Nurses' Association (2019) argues that there exists a need for school nurses to have reasonable workloads to be able to fulfill their assignment to contribute to a good learning environment in schools and to offer all students equal health promotion efforts.
Health promotion is, according to the WHO (1986), "the process of enabling people to increase control over, and to improve, their health. To reach a state of complete physical, mental, and social well-being, an individual or group must be able to identify and realize their aspirations, to satisfy their needs, and to change or cope with their environment" (p. 1). The process of increasing human beings' control of their health is enhanced when they are heard and perceive their contributions as valued (WHO, 1998). There is a body of research on student voice that contends students have much to teach us in terms of developing and improving educational programs, fostering engagement, and creating opportunities to enhance health promotion (Kidd \& Czerniawski, 2011; Peacock, 2006; Warne, 2013). Participatory research empowers people by giving them a voice and space to, in a democratic spirit, share their experience (Ghaye et al., 2008).

Paakari et al. (2018) found that high levels of health literacy are positively related to school achievement in students' first language and educational aspirations. According to Kickbusch (2012), health literacy is more important in $21^{\text {st }}$ century than ever before in order to live a good and healthy life, due to changes in society for example; health challenges related to unsustainable lifestyles and unsustainable production and consumption patterns, increased migration and 'the hurry virus' contributing to time pressure and increased stress, anxiety and depression. According to Nutbeam (2002), health literacy is "a composite term to describe a range of outcomes to health education ... and, from this perspective, health education is directed at improving health literacy" (p. 259). Nutbeam's (2002) concept of health literacy consists of three levels that can be used to understand the practice of health promotion, which aims to instill and maintain personal and community health (Sykes et al., 2013; Paakari \& George, 2018). The first level, functional health literacy, represents the traditional health education goals of increasing knowledge about health risks and how to use the 
health care system. The second level, interactive health literacy, reflects activities directed toward developing personal skills through a supportive environment. The third level, critical health literacy, reflects addressing social, economic, and environmental determinants of health using cognitive, interpersonal, and social skills (Nutbeam, 2002). The health dialogues, if successfully administrated, may have the potential to contribute with all or some parts of the three-level health literacy concept in healthpromoting schools. The current study aimed to explore how health dialogues are experienced by school actors - students, teachers and school nurses.

\section{Study Design}

\section{Methods}

To capture the participants' experiences with health dialogues, a phenomenological study design inspired by van Manen (1997) was applied. van Manen (1997) explains that the most straightforward way to investigate a phenomenon is asking individuals to write down their experiences, as writing separates us from what we know and brings us closer to it. We used semistructured, open-ended writing - open letters - to allow participants to express original individualized responses (cf. Kostenius, 2008). Specifically, the participants were asked to finish the following sentences: "Now I will tell you about my experiences with the health dialogues..." (to students and teachers) and, "Now I will tell you about my experiences with holding health dialogues..." (to the school nurses). These open letters were distributed to those who agreed to take part in the study either in paper or digital form.

\section{Participants}

All school nurses in the most northern region of Sweden (14 municipalities) were invited to participate in addition to teachers and students from three municipalities. A total of 93 participants agreed to partake including 44 school nurses from across the entire region, 37 students in grades 4, 7, and the first year of high school, and 12 teachers from three schools in three municipalities.

\section{Data Collection}

This study was approved by the local ethics committee [2017/403-31], and voluntary participation and confidentiality were explained in the invitation to take part in the study (SFS 2003:460). The first author visited meetings at the regional network for all school nurses (approximately 50-55 school nurses employed in the region's 14 municipalities) on three different occasions and distributed the open letters in both paper and digital form. Most of the school nurses completed the open letters on paper during the meeting or returned them by mail to the first author, while some of them responded in digital form. The first author and $\mathrm{LN}$ (see acknowledgments) contacted three schools in different municipalities in the region, inviting all students in grades 4 in one school, grade 7 in one school, and the first year of high school in one school and the teachers in those grades to participate in the study. The students and teachers submitted their open letters to the first author anonymously online.

\section{Analysis}

The open letters were analyzed in two stages inspired by van Manen (1997): seeking meaning and theme analysis. Both authors took part in the first and second steps with three additional colleagues: LN, AH, and AN (see acknowledgments). Seeking meaning involved the authors and their colleagues reading all of the open letters several times. A mind map was created collectively to obtain a sense of the whole picture. The second step, theme analysis, consisted of identifying experiential structures within the data and looking for differences, similarities, and patterns. Individual analyses were discussed to form a consensus and combined into themes, guided by the following questions: What are the participants' experiences with health dialogues? What are their experiences with holding, participating in, or facilitating health dialogues? Inspired by van Manen (1997), 
participants' health dialogue experiences were organized into broad themes and named accordingly. Finally, illustrative quotations were selected by the two authors that exemplify each theme to give voice to the participants and, according to Polit and Beck (2004), enhance credibility.

\section{Results}

The phenomenological analysis resulted in two themes with three sub-themes each (Table 1).

Table 1.

Themes and Sub-themes Illuminating Participants' Experiences with Health Dialogues

\begin{tabular}{|c|c|}
\hline Theme & Sub-themes \\
\hline $\begin{array}{l}\text { On the highway } \\
\text { to health }\end{array}$ & $\begin{array}{l}\text { Doing good } \\
\text { Speaking up } \\
\text { Connecting the dots }\end{array}$ \\
\hline $\begin{array}{l}\text { Signs of danger } \\
\text { ahead }\end{array}$ & $\begin{array}{l}\text { Lacking time and support } \\
\text { Feeling stranded on an } \\
\text { island } \\
\text { Dropping the ball }\end{array}$ \\
\hline
\end{tabular}

\section{On the Highway to Health}

The participants' narratives conveyed positive experiences that exemplified that they were on the right track. Their descriptions of health dialogues being experienced as positive are further explored in three sub-themes: Doing good, Speaking up, and Connecting the dots.

Doing Good. According to the participants, the mandatory health dialogues increases opportunities to build health-promoting relationships. One school nurse said, "First of all, it is great because I get to meet and follow students from preschool class all the way up to high school ... I think it is absolutely amazing ... building relationships with all of the students." The participants described how health dialogue enables professionals to better explain healthrelated issues to students and to understand which issues are most important to students. One student wrote, "It helps teachers understand us better. And when the teachers understand us, we learn much better and faster." The professionals used health dialogues as a means of caring for and helping students. For school nurses, health dialogues served to inform teachers and helped indirectly by facilitating dialogues between students and teachers. One teacher wrote, "The school nurse came to me after she had completed the health dialogues to talk about (the student's) 'individual problems' ... I was astonished and pleasantly surprised at the width of the questions and I understand that the information that the school receives via the health dialogues is very valuable!"

The participants' descriptions revealed how the personal (student), group (classroom), and organizational (school) levels are interwoven, which highlights the need to view health dialogues as beneficial not only for the students individually but the entire school's collective learning environment as well. One student wrote, "Since learning in school is easier and better if your health is good, it is better for the (whole) school." The participants relayed their appreciation for the opportunity to do good and were proud of their ability to make a positive impact. The nurses also reported that receiving support from fellow professionals was helpful to the students. One school nurse wrote, "At my school, I'm never questioned when I'm holding the health dialogues; on the contrary, the teaching staff think that it is important and communicate this to the students, which is very important for the health dialogue."

Speaking Up. According to the participants, health dialogues can empower individuals and groups by giving them a say in matters affecting them. Health dialogue was seen as a way to build a supportive school environment and enable individuals to be their best by increasing their sense of control over their health. They perceived health dialogue as lowering the threshold for asking for help. One teacher wrote, "I think the 
health dialogues are useful; my experience is that the students are getting more confident about visiting the school nurse on their own."

The participants all appreciated that engaging in health dialogues informed students about good health practices while at school. They also shared examples of ways to improve health dialogues. One student wrote, "I liked the health dialogue, but I think there should be more questions about mental health, as many young people suffer from this nowadays. I have suffered from mental illness and I think it is important that grown-ups know that when children are not feeling well, they try to look like everything is alright. I know how it feels."

Connecting the Dots. The participants shared examples of health dialogues being used on a structural level to connect actions with positive results. For example, the results from the health questionnaires were included in the school improvement plan and followed up on in annual quality assessment reports to the Ministry of Education. When the professionals acknowledged health dialogue and the health questionnaire as part of their professional duties, these were integrated into daily work tasks. One school nurse wrote, "In many schools, it is a natural part of the health promotion and disease prevention work and everyone, the principal and teachers, are aware of the purpose of the health dialogues and are curious about the results."

According to the participants there were different means of sharing the results from the health dialogues and health questionnaires. They narrate about school nurses and teachers giving feedback based on the results from the health questionnaires to individual students or communicated to student groups. On the individual level (communications between a school nurse and a single student), the participants appreciated the opportunity to foster dialogue and receive feedback. According to the participants, the dialogue itself was valuable and the health issues discussed in the conversation were much appreciated. One student wrote, "It was a wake-up call for me when I saw what my eating and sleeping habits look like when written down on paper." Experiences of shared responsibility among professionals in the school arena were evident. One school nurse wrote, "When I receive the results at the end of the year, I present it to the class and I also speak about health and how the students can influence their own health. I also present the results to the student health team at the school where we analyze the results together and agree on how to take appropriate actions."

\section{Signs of Danger Ahead}

The participants' narrations also included negative experiences concerning how health dialogues complicate health promotion in school. Their descriptions of the negative aspects of health dialogues are further explored in three subthemes: Lacking time and support, Feeling stranded on an island, and Dropping the ball.

Lacking Time and Support. The lack of time and support was evident in the participants' narratives; however, different experiences were reported in connection to this sub-theme. According to the participants, the time allotted for school nurses to hold health dialogues was not sufficient. The same was true regarding the amount of time available to thoroughly deal with the results of the health dialogues, such as helping students with specific needs that surfaced during the health dialogue. According to one teacher, "It is sometimes difficult to find time slots suitable to gather all ... then it takes too long before the student or the school receives the help needed." The school nurses reported having insufficient time to complete their health promotion assignments, which includes health dialogues. One nurse wrote, "From a health-promoting perspective, we should meet the students every year and arrange health promotion activities. But there is no time for this to happen."

Equally, some accounts indicated that teachers lack the time to support students who go to the 
school nurse for their health dialogue, as this interrupts their daily educational work. Leaving the classroom puts students at risk of missing important lessons. One nurse wrote, "Oftentimes, it is an obstacle both in terms of my own time and to the teachers, as they do not want to 'let go of' the students from their lessons for too long." Successfully promoting health in school also seemed to depend on the grade of the student. Another nurse reported, "Teachers in the compulsory school are often positive and willing to cooperate (with us school nurses) for us to carry out the health dialogues. At the high school, we sometimes encounter a little resistance; they do not want to be disturbed and 'let go of' their students." Another school nurse summed up the lack of time and support by writing, "We need more time for follow-up with the students who are in need. We seldom have time for following up with these children even though we would like to. I wish there was more time for information about the importance of the health dialogues. There is a lack of time (to do this)..."

Feeling Stranded on an Island. The participants described how a lack of cooperation and connection between staff and students prevented them from satisfactorily engaging in the process of health promotion. The lack of cooperation was described as stemming from disinterested and uninformed co-workers who did not see the students' health as their responsibility. One teacher wrote, "Health dialogues are something I didn't know existed. Or, rather, something I just thought the school nurse was to be involved with. Sorry..." Along the same lines, a school nurse wrote, "The teaching staff have no idea about the health dialogues, not the content nor the purpose of them. They are not interested in the results, either." Some of the school nurses' experiences revealed that there can be limited interest from teachers, which complicates collaboration. One teacher wrote, "I have no personal experiences with the health dialogues other than that I have distributed envelopes with information to the guardians. I don't even know what these health dialogues are about..."
The participants' narratives revealed a feeling of separation between the teaching assignment and information about health promotion and disease prevention. This was evident at the team level, for example, among the teaching and health staff in a single grade and at the organizational level, throughout an entire school. While many school nurses expressed a desire to involve teachers, the teachers often expressed a lack of time and knowledge about health issues. One teacher wrote, "I don't know when the health dialogues are taking place nor what the results are..." The participants also described school leaders who do not consider health dialogues to be part of the school's mission, which is reflected in administrative decisions such as which professionals are hired and which issues are put on the school agenda. One school nurse wrote, "... all teachers are extremely protective of their classroom time, so we can almost never work at the group level. The principal doesn't prioritize the student health work ..." Another school nurse wrote, "At some schools, the school's management and the teaching staff show no or little interest in hearing about the results (of the health dialogues). They do not see the potential of working with the results. It can even become a problem for some teachers when the students are to be away from the classroom to have their health dialogues."

Dropping the Ball. Some of the school nurses reported a lack of engagement among staff members and school leaders to fully engage in the health dialogue process. One school nurse wrote, "We need the teaching staff to get on board and understand the importance of health dialogues. It is crucial that the results of the health dialogues are taken seriously by the whole school and are used regularly and systematically for health promotion efforts in school." The participants identified the need to address challenges that was found in the results at the appropriate level. A school nurse expressed, "Working with the results at the group and organizational levels is more difficult than working with each individual student, as there is no mandate (for me) to work 
on the group level." The participants reported that the absence of a mandate to work with a group of students and the lack of support for health promotion at the organizational level results in problems easily are written off as individual students' problem. One school nurse wrote about not having an arena in which the results of health dialogues could be presented and discussed: "Unfortunately, there is limited opportunity to bring back (the results) to the entire school class or undertake preventive measures based on what emerges from the health dialogues. Then the prevention work is usually done on an individual level during the health dialogue." Another school nurse wrote about the "need to develop processes and change the way school health promotion and (disease) prevention is done so that the child's individual experiences based on experiences on the group and organizational levels are also addressed on the group and organizational levels."

Furthermore, there seemed to be a lack of faith among students about the usefulness of health dialogues. One student felt that the health dialogue was too short "... and the wellbeing of students are not taken seriously." According to the participants, support from school leadership is much needed but often lacking. One nurse wrote, "In order for the health dialogues and their results to promote the students' health and learning, the health dialogues must be naturally incorporated in the schools (organization), which is the case in many schools, but there is a need for more information and guidelines from above on how the results should be used."

\section{Discussion}

This study aimed to explore how health dialogues are experienced by school actors - school nurses, teachers, and students. Our phenomenological analysis yielded themes and sub-themes that described well-functioning health-promoting schools in which health promotion was seen as a shared practice among staff. In contrast, participants also expressed frustration and resignation with the challenges connected to practicing health dialogues. Furthermore, the participants' narratives contained all three levels of health literacy described by Nutbeam (2002), despite the great differences between schools in terms of progress toward promoting health literacy. Some participants described health dialogues as helpful in promoting health literacy at all three levels, enabling collaboration between different actors within the school, and connecting health educators and teaching staff. Some participants described health promotion as nonexistent or health literacy existing only on the first or second of Nutbeam's (2002) three levels, which represent shortcomings that warrant being addressed.

Simovska's (2012) question "What do healthpromoting schools promote?" was explored in the present study concerning the concept of health literacy. The findings reflected functional health literacy practices (level 1) that focus on providing information to increase awareness of health risks in the sub-theme Doing good. Health dialogue and the health questionnaire were, according to the participants, valuable, greatly appreciated, and the topics covered were relevant to their lives. However, represented by the sub-theme Lacking time and support, school nurses were dissatisfied with the time allotted to inform, discuss, and support students' health literacy. Moreover, the perceived lack of cooperation and resources dedicated to promoting health literacy rendered health dialogues less helpful than intended. According to Bruun Jensen and Simovska (2005), the empowerment aspect of health education is of utmost importance, as it is highly unlikely that it will lead to positive changes in students' behaviors without their developing ownership.

Interactive health literacy (level 2), activities aimed to develop personal skills in a supportive environment, was exemplified in the sub-theme Speaking up. The participants reported that the health dialogue in itself created an empowering environment within the school, enabling individuals to be their best by providing a sense 
of control over their health. Yet, according to Peacock's (2006) argument, to foster an ethical, trusting, and supportive environment the entire school organization must have the opportunity to participate and make their voices heard. As such, health literacy would be promoted by extending these activities to the group and organization level going forward.

Critical health literacy (level 3), the cognitive, interpersonal, and social skills required to address the social, economic, and environmental determinants of health, was exemplified in the sub-theme Connecting the dots. The participants - students, teachers and school nurses alike expressed that cooperation and connection between staff and students facilitated effectively promoting health literacy. However, reflected in the sub-theme Feeling stranded on an island, a lack of cooperation was described by school nurses in the form of disinterested and uninformed teaching staff and school leadership members who do not see students' health as their responsibility. Along the same lines, in the subtheme Dropping the ball some of the school nurses reported a lack of engagement among staff members and school leaders to fully engage in the health dialogue process. To be successful promoting critical health literacy the health dialogues and the health questionnaires must be viewed as a task not only for health professionals but also for the teaching staff, principals, and local politicians in addition to students and their parents.

Furthermore, strong school leadership is essential to sustain health promotion practices, which requires identifying student health champions in leadership roles within educational organizations. According to Dadaczynski et al. (2020), health literacy is linked to the implementation status of health-promoting schools and school leaders with sufficient health literacy levels are more likely to garner higher levels of health-promoting implementations. The school leadership must be able to apply their individual-level abilities in an organizational context to support a variety of inschool health-promoting activities.

However, health dialogues and the results from the health questionnaires on an individual level are strictly confidential as they fall under the Swedish Publicity and Secrecy Act (SFS, 2009:400). While this must be respected, the participants described how the individual, group, and organizational levels are interwoven in practice. This supports the need to view health dialogues as beneficial not only for the individual students but for the entire school environment. According to Leahy and Simovska (2018), a critical perspective in health promotion research sets an agenda for policy and curriculum development that considers the wider determinants of health and is aimed at the development of students' comprehensive healthrelated competencies rather than the regulation of their behavior.

The findings from the present study indicate that different school actors experience health dialogues very differently. Concerning their positive experiences, the sub-theme Connecting the dots illustrates that health dialogues are a necessary part of health promotion and disease prevention efforts. When school leaders and teachers are familiar with the purpose and results of the health questionnaires effective health literacy promotion practices are made possible. The sub-theme Doing good illustrates experiences of health dialogues being used as tools for reactive interventions, to identify and help students with health-related issues. Additionally, the health-promoting benefits of health dialogues were described by participants at many levels within the school organization, including health promotion efforts on the individual, group, and organizational levels. This echoes Gugglberg and Dür (2011), who argue that schools need support from their environment in terms of building resources and institutionalizing health promotion into their core and management practices. 
Many of the school nurses' and teachers' negative experiences arose from the apparent discrepancy between what is expected of them and what they de facto are practicing in accordance with current government policy provisions (SFS2010:800; Swedish National Board of Health and Welfare \& Swedish National Agency for Education, 2016). The findings show that there seem to be inconsistencies in the implementation of this policy. According to Sweden's municipalities and county councils (SKL, 2018), one of the most challenging tasks for educational systems is how to develop and implement effective health promotion and disease prevention efforts.

\section{Limitations}

This study was conducted in Sweden where health dialogues are mandated by law, which is not the case globally and thus hinders transferability. However, the results of this study are transferable to schools in other regions of Sweden and other countries facing similar challenges with regards to health promotion.

\section{Conclusion}

When given a voice, school actors paint a collective picture of health dialogues including examples of successful practices and areas of improvement. Based on our findings, we argue that health dialogues can help to promote students' health literacy and enable collaboration between different professions within educational systems. The participants' experiences with health dialogues speak to a co-creation that transcends age and profession. Following Nutbeam's (2002) and Kickbusch's (2012) lines of reasoning and given that health education serves to improve health literacy, we argue that in-school health promotion must be viewed as a responsibility shared by all staff members for health dialogues to effectively support healthy practices among students. Furthermore, promoting health literacy in schools must be treated as a common assignment for all school staff, and leadership support is needed to systematically integrate the results from health dialogues into effective health promotion practices. However, the current conditions found in some schools and municipalities do not enable fostering effective health dialogues. In these cases, additional leadership and governmental support is needed to ensure greater equity in health promotion is sustainably implemented and maintained, in line with Haglund and Tillgren's (2009) reminder that the main focus of promoting health literacy is social justice. The findings could also inform policy making in countries looking to enact health promotion mandates.

\section{References}

Backman, Y., Alerby, E., Bergmark, U., Gardelli, Å., Hertting, K., Kostenius, C., \& Öhrling, K. (2012). Learning within and beyond the classroom: Compulsory school students voicing their positive experiences of school, Scandinavian Journal of Educational Research, 56, 555-570. doi: $\underline{10.1080 / 00313831.2011 .621138}$

Bruun Jensen, B., \& Simovska, V. (2005). Involving students in learning and health promotion processes - clarifying why? what? and how? IUHPE-Promotion and Education, XII, 3-4, 150-156. doi: $10.1177 / 10253823050120030114$

Dadaczynski, K., Rathmann, K., Hering, T \& Okan, O. (2020). The role of school leaders' health literacy for the implementation of health promoting schools, International Journal of Environmental Research and Public Health, 17, 1855; doi:10.3390/ijerph17061855.

SFS. (2003:460). Law on ethical approval of research on human beings. Retrieved March 22, 2021, from website, https://www.riksdagen.se/sv/Dokument-Lagar/Lagar/Svenskforfattningssamling/Lag2003460-om-etikprovning_sfs-2003-460/ 
Ghaye, T., Melander-Wikman, A., Kisare, M., Chambers, P., Bergmark, U., Kostenius, C., \& Lillyman,

S. (2008). Participatory and appreciative action and reflection (PAAR) - democratizing reflective practices, Reflective Practice, 9, 361-397. doi: 10.1080/14623940802475827

Golsäter, M. (2012). Hälsosamtal som metod att främja barn och ungdomars hälsa: en utmanande uppgift [Doctoral thesis, Jönköping University]. https://ju.se/download/18.5768b449151aa56d81ed2b3f/1520578748023/FULLTEXT01.pdf

Gustafsson, J.-E., Westling, A.M., Alin Åkerman, B., Eriksson, C., Eriksson, L., Fischbein, S., Granlund, M., Gustafsson, P., Ljungdahl, S., Ogden, T., \& Persson, R.S. (2010). School, Learning and Mental Health: A Systematic Review, The Royal Swedish Academy of Sciences, Stockholm. website, https://www.semanticscholar.org/paper/a74824f3c2ef50084b63b2f97415cececc4ac4a2

Gugglberger, L., \& Dür, W. (2011). Capacity building in and for health promoting schools: Results from a qualitative study, Health Policy, 101, 37-43. doi: 10.1016/j.healthpol.2010.08.019

Haglund, B., \& Tillgren, P. (2009). Forskning i hälsofrämjande arbete - ett interventivt forskningsområde med syfte att bidra till större social rättvisa, Socialmedicinsk tidskrift, 2, 128-138. website, https://www.researchgate.net/profile/BoHaglund/publication/277855383_Forskning_i halsoframjande arbete ett interventivt forskningsomrade med syfte att bidra till storre social rattvisa/links $/ 563 \mathrm{cc} 6$ c108aec6f17dd7d686/Forskning-i-haelsofraemjande-arbete-ett-interventivt-forskningsomrademed-syfte-att-bidra-till-stoerre-social-raettvisa.pdf

Kickbusch, I. (2012). Health literacy: an essential skill for the twenty-first century, Health Education, 108, 2, 101-104. doi: 10.1108/09654280810855559

Kidd, W., \& Czerniawski, G. (2011) (Eds.). The Student Voice Handbook, Emerald Publishing, London.

Kostenius C. (2008). Giving voice and space to children in health promotion, Doctoral thesis, Department of Health Science, Luleå University of Technology, Sweden. website, https://scholars.fhsu.edu/cgi/viewcontent.cgi?article=1359\&context=alj

Leahy, D., \& Simovska, V. (2018). School health education and promotion: current approaches and critical perspectives: part 2, Health Education, 118, 2, 114-116. doi: 10.1108/HE-12-2017-0068

Nutbeam, D. (2000). Health Literacy as a public health goal: a challenge for contemporary health education and communication strategies into the 21 st century, Health Promotion International, 15, 3, 259-267. doi: 10.1093/heapro/15.3.259

Paakari, O., Torppa, M., Villberg, J., Kannas, L., \& Paakkari, L. (2018). Subjective health literacy among school-aged children, Health Education, 118, 2, 182-195. doi: 10.3390/ijerph16183397

Paakari, L., \& George, S. (2018). Ethical underpinnings for the development of health literacy in schools: ethical premises ('why'), orientations ('what') and tone ('why'). BMC Public Health, 18, 326, doi: 10.1186/s12889-018-5224-0.

Peacock, A. (2006). Escaping from the bottom set: finding a voice for school improvement, Improving Schools, 9, 3, 251-260. doi: 10.1177/1365480206072151

Region Norrbotten (2017). Skolbarns hälsa och levnadsvanor $i$ Norrbotten. Rapport för läsåret 2015/2016. [School children's health and living habits in Norrbotten. Report for the academic year 2015/2016]. Luleå: Author. website, https://www.norrbotten.se/publika/lg/utv/Folkh\%C3\%A4lsocentrum/Rapporter/Skolelevers $\% 20 \mathrm{~h}$ \%C3\%A41sa\%202015-2016/skolbarns halsa 2016 rapport 161117.pdf

Rising Holmström, M., Häggström, M., \& Kristiansen, L. (2015). The transformation of the school nurse's role towards the new health-promoting position, Nordic Journal of Nursing Research, 35, 4, 210-217. doi: 10.1177/0107408315587860 
Rising Holmström, M., Asplund, K., \& Kristiansen, L. (2013). Promoting a relationship- based health practice: A challenge for school nurses, British Journal of School Nursing, 8, 1, 30-38. doi: 10.12968/BJSN.2013.8.1.30

SFS. (2010:800). Swedish School Law. Retrieved March 18, 2020, from website, http://www.riksdagen.se/sv/dokument-lagar/dokument/svensk-forfattningssamling/skollag2010800 sfs-2010-800

SFS (2009:400). Swedish Publicity and Secrecy Act. Retrieved March 11, 2021, from website, https://www.riksdagen.se/sv/dokument-lagar/dokument/svensk-forfattningssamling/offentlighets-och-sekretesslag-2009400 sfs-2009-400

Simovska, S. (2012). What do health-promoting schools promote?: Processes andoutcomes in school health promotion, Health Education, 112, 2, 84-88. Doi: https://doi.org/10.1108/09654281211214527

SKL. (2018). Nuläge och utmaningar i elevhälsan 2018. Retrieved March 18, 2020, from website, https://webbutik.skl.se/sv/artiklar/nulage-och-utmaningar-i-elevhalsan-2018.html

Swedish National Agency for Education (2010). Läroplan för grundskolan, förskoleklassen och fritidshemmet. Lgr 2011, Skolverket, Stockholm. website, https://www.skolverket.se/download/18.6bfaca41169863e6a65d48d/1553968042333/pdf3975.pdf

Swedish National Board of Health and Welfare and Swedish National Agency for Education (2016). Vägledning för elevhälsan. Retrieved March 18, 2020, from website, http://www.socialstyrelsen.se/publikationer2016/2016-11-4

Swedish school nurses association (2019). Styrelsens klargörande kring antal elever/heltid skolsköterska. [The board's clarification regarding the number of students / full-time school nurse]. Retrieved March 22, 2021, from website, https://www.skolskoterskor.se/wpcontent/uploads/2019/04/Klargörande-gällande-nyckeltal-2019.pdf

Sykes, S., Wills, J., Rowlands, G., \& Poople, K. (2013). Understanding critical health literacy: a concept analysis, BMC Public Health, 13, 150. doi: 10.1186/1471-2458-13-150

Van Manen, M. (1997). Researching Lived Experience: Human Science for an Action Sensitive Pedagogy, Althouse, London. website, https://www.worldcat.org/title/researching-livedexperience-human-science-for-an-action-sensitive-pedagogy/oclc/37195833

Warne, M. (2013). Där eleverna är. Ett arenaperspektiv på skolan som en stödjande miljö för hälsa. Doctoral thesis, Mid University, Sweden. website, http://urn.kb.se/resolve?urn=urn:nbn:se:miun:diva-20149

WHO. (1986). The Ottawa Charter for Health Promotion. Retrieved March 18, 2020, from website, http://www.who.int/healthpromotion/conferences/previous/ottawa/en/index4.html

WHO. (1998). Health Promotion Evaluation: Recommendations to policy-makers. Retrieved March 18, 2020, from website, http://apps.who.int/iris/bitstream/handle/10665/108116/E60706.pdf

\section{Acknowledgments}

We would like to thank the participating students, teachers and school nurses, the heads of education and school principals in the municipalities, and also the parents to the participating students. We appreciate the contributions of our colleagues during the data collection process and the analysis; Lena Nyström (LN), Annica Henriksson (AH) from Norrbotten Association of Local Municipalities and Annika Nordstrand $\mathrm{PhD}$, Director of Public Health at Region Norrbotten. This study was supported by the Norrbotten Association of Local Municipalities and the Department of Health, Education and Technology at the Luleå 
University of Technology in Sweden and was financed by Riksbankens Jubileumsfond - the Swedish Foundation for Humanities and Social Science.

Corresponding Author Information

Catrine Kostenius

Department of Health, Education and Technology

Luleå University of Technology

97187 Luleå

Sweden

Phone: +46 (0)920-491000

+46 (0)70-2000464

E-mail: catrine.kostenius@1tu.se 